\title{
Human organ and tissue transplantation in Pakistan: when a regulation makes a difference
}

\author{
K.M. Bile, J.A.R.H. Qureshi, ${ }^{1}$ S.A.H. Rizvi, ${ }^{2}$ S.A.A. Naqvi, ${ }^{2}$ A.Q. Usmani ${ }^{3}$ and K.A. Lashari4
}

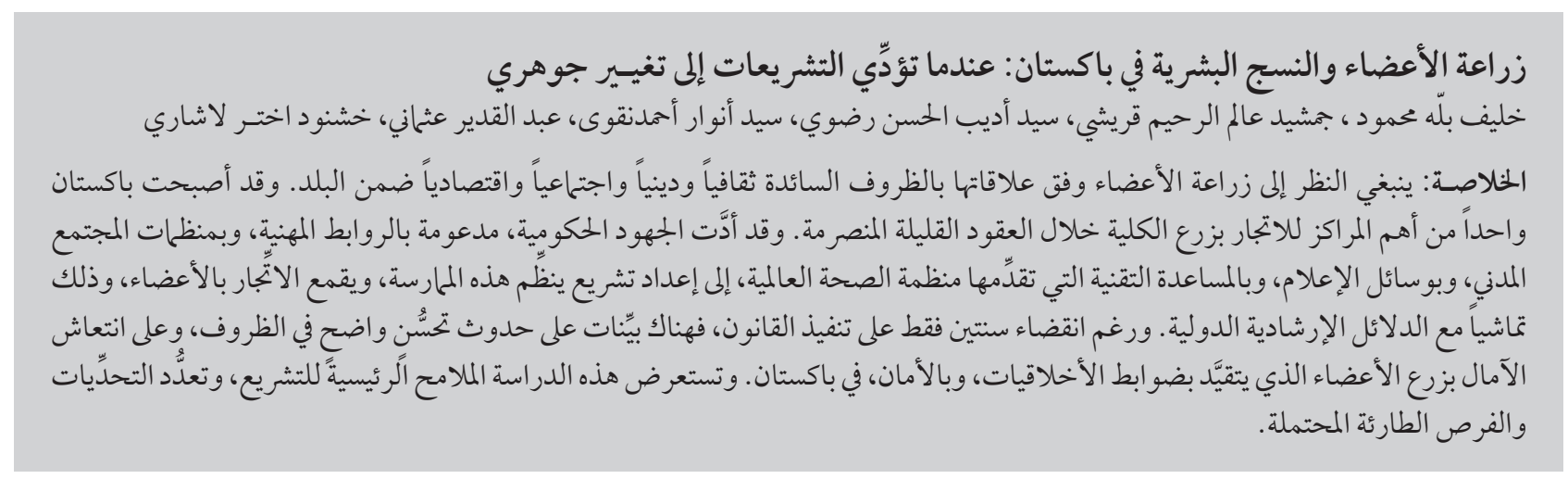

ABSTRACT Organ transplantation must be viewed in relation to the prevailing cultural, religious and socioeconomic conditions of a nation. Over the past two decades, Pakistan has emerged as one of the largest centres for commercial renal transplantation. Government efforts, supported by professional associations, civil society organizations and the media, along with World Health Organization technical assistance, have led to the development of legislation regulating this practice and curbing organ trade in conformity with international guidelines. Although only two years have passed since the enactment of the law, there is evidence that conditions have significantly improved, raising hopes for ethical and safe organ transplantation in Pakistan. This study reviews the salient features of the legislation and lists the foreseeable evolving challenges and opportunities.

\section{Transplantation d'organes et de tissus humains au Pakistan : lorsque la loi fait la différence}

RÉSUMÉ Les transplantations d'organes doivent être envisagées en tenant compte des valeurs culturelles et religieuses d'un pays, ainsi que de ses conditions socioéconomiques. Au cours des vingt dernières années, le Pakistan est apparu comme l'un des plus hauts lieux du commerce de la transplantation rénale. L'action gouvernementale, soutenue par les associations professionnelles, les organisations de la société civile et les médias, avec l'assistance technique de l'Organisation mondiale de la Santé, a conduit à la rédaction d'une loi régissant ces pratiques et contribuant à réduire le commerce d'organes, conformément aux directives internationales. Même si sa promulgation ne remonte qu'à deux ans, il est évident que la situation s'est considérablement améliorée, ravivant l'espoir de transplantations éthiques et sûres au Pakistan. Cette étude analyse les principales caractéristiques de la législation et récapitule les futurs défis et opportunités prévisibles.

${ }^{7}$ World Health Organization, Country Office, Islamabad, Pakistan (Correspondence to K.M. Bile: bilek@pak.emro.who.int).

${ }^{2}$ Sindh Institute of Urology and Transplantation, Karachi, Pakistan.

${ }^{3}$ Human Organ Transplantation Authority, Islamabad, Pakistan.

${ }^{4}$ Ministry of Health, Islamabad, Pakistan. 


\section{Introduction}

Human organ transplantation, involving the therapeutic use of organs obtained from healthy living or deceased donors, is the last resort for the survival and wellbeing of thousands of men, women and children suffering from end-stage organ failure $[1,2]$. This essential medical service is viable only when the required professional skills and ethically approved, quality institutions are available and when governed by sound legislation that generates sufficient societal support [3]. At a global level, progress in setting universal guidelines has been made by the World Health Organization (WHO), the World Medical Association and the international Transplantation Society $[4,5]$. The guidelines cover:

- organ donation by living adults;

- legal consent for organ removal from deceased persons;

- averting conflict of interest related to a physician's death determination;

- banning exploitation and coercion;

- barring remuneration exceeding a justifiable fee for services rendered by persons and for facilities involved in organ procurement and transplantation;

- allocating organs, cells and tissues based on clinical need;

- establishing criteria guaranteeing that the result outcomes are transparent and open to scrutiny, while at the same time protecting personal anonymity and privacy of donors and recipients $[4,5]$.

During the past half century this field has progressed to a technologically advanced clinical specialty, although the practice of organ donation involves sociocultural, legal and ethical challenges [6].

Over a prolonged period, Pakistan has emerged as one of the largest known centres for renal trafficking owing to a lack of regulation and the presence of a large vulnerable rural population creating a thriving market for kidney sales $[7,8]$.

As in the rest of the Islamic world, the development of organ transplantation legislation in Pakistan moved slowly, owing to the lack of an outright consensus on religiously motivated ethical questions regarding the practice. Key questions included:

- Does religion allow organ donation and, if granted, are restrictive conditions attached?

- Is donation limited to relatives only?

- Can organs be sold or is bestowing rewards and grants to donors acceptable?

- Can organs be obtained from the deceased, and how and when can death be firmly ascertained?

- Is the act of donation an exclusive donor's right or are relatives of the deceased allowed to donate and can the Government perform this act in the case of unclaimed deceased persons?

- Is xenotransplantation permissible $[8,9]$ ?

Most of these challenging queries were resolved and consensus deliberation attained through the promulgation of legitimate verdicts (fatwas) originated by Islamic scholars of jurisprudence such as the Al-Azhar of Egypt, the Council of Senior Scholars in Saudi Arabia, the International Union of Islamic Jurisprudence, the Union of Islamic Jurisprudence affiliated with the International Islamic Association and by many regional associations [9]. In the Islamic world, it is often mandatory to ensure that legislation, including that relevant to organ donation, does not contradict the teachings of Islam, a responsibility undertaken by officially constituted Islamic foundations providing legal opinions, including those relevant to the health and population sector. These foundations put an end to misconceptions and speculation, generate public acceptability and lead to greater service utilization.
In the global debate on transplantation, Islamic rulings have substantiated the legitimacy and religious acceptability of organ donation, consistent with the internationally set ethical and technical norms; however, the sale of organs and exploitative coercive donations were termed un-Islamic [9]. To ensure correct transplantation norms, the Government of Pakistan has successfully promulgated legislation. This study aims to review the salient features of the legislation and its compatibility with international ethical transplantation guidelines. It also lists evolving challenges and foreseeable opportunities for building an ethically focused national capacity for this vital service.

\section{Methods}

A desk review was conducted on the available literature in this specialized discipline using MEDLINE. In addition, literature on the historical processes and challenges regarding the regulation of organ transplantation in Pakistan, along with the recorded contributions made by different partner institutions, was studied. WHO literature in the context of this legislation, especially the set normative guidelines for organ transplantation, was also reviewed as well as the Islamic verdicts on key religiously and ethically charged questions related to organ donation.

\section{Organ transplant legislation}

Prior to the legislation, the unethical practice of organ transplantation was constantly a major concern since renal transplantation surgery took root in Pakistan in early 1973. Institutions pursuing and supporting ethical guidelines for life-saving organ transplantation were led by the Sindh Institute of Urology and Transplantation. This institute was founded in 1972 and became an 
autonomous institution in 1991 and is the largest centre in Pakistan offering free dialysis and transplantation services to the underprivileged, with a legacy of 2700 transplants until 2009. However, commercial kidney transplantation flourished in many other institutions in Pakistan, where organs were advertised for sale on the Internet. In early 2005, an Internet search for "kidney transplantation in Pakistan" generated more than 800000 entries. Key milestones in the practice of kidney transplantation in Pakistan and the chronological events that combated organ trade and led to the successful enactment of legislation are summarized in Table 1.

\section{Transplantation ordinance: efforts, achievements and challenges}

Following the intervention by the $\mathrm{Su}$ preme Court of Pakistan in July 2007, an ordinance to regulate organ transplantation and curb the burgeoning kidney trade was drafted by the Ministries of Health and Law. The Transplantation of Human Organs and Tissues Ordinance 2007 was then promulgated by the President of Pakistan, regulating the removal, storage and transplantation of human organs and tissues for therapeutic purposes and related procedural matters all over the country. The principal features of the ordinance, later promulgated as an act, are summarized below.

\section{Donation of organ or tissue by a living person}

The ordinance stipulated that a donor should not be less than 18 years of age, donation should be a voluntary act and that donation should be permissible to a living person genetically and legally related, i.e. a close blood relative. In the case of regenerative tissues, such as stem cells, there was no restriction of

\begin{tabular}{|c|c|}
\hline Year & Events \\
\hline 1979 & Renal transplantation started in Pakistan in public sector hospitals using living related family donors \\
\hline \multirow[t]{2}{*}{ 1990s } & $\begin{array}{l}\text { Renal transplantations exceeded } 500 \text { transplantations per year with first violations observed, whereby some } \\
\text { hospitals shifted from dealing exclusively with living, related donor to unrelated, paid donors until these } \\
\text { unethical practices accounted for more than } 80 \% \text { of all transplantations. Later in the decade transplantations } \\
\text { exceeded } 1000 \text { per year. }\end{array}$ \\
\hline & $\begin{array}{l}\text { A transplantation bill was introduced by the Senate in 1992, based on ethical norms and conforming to World } \\
\text { Health Organization (WHO) and International Transplantation Society guidelines, but the attempt was defeated } \\
\text { by the then strong counter lobby. }\end{array}$ \\
\hline 2000 s & $\begin{array}{l}\text { Opposition to promulgating the law was sustained and commercial kidney transplantation flourished with over } \\
1500 \text { expatriates receiving locally procured kidneys. The Ministry of Health, supported by SIUT, media and civil } \\
\text { society organizations, sustained its efforts to promote legislation and bring an end to these unethical practices. } \\
\text { WHO provided the necessary technical support through its country, regional and headquarter institutions. }\end{array}$ \\
\hline 2004 & $\begin{array}{l}\text { A bill was tabled in the Pakistan Senate by a member raising the momentum for action. Subsequently, the subject } \\
\text { was tabled as an agenda item in the Federal Cabinet. }\end{array}$ \\
\hline 2006 & $\begin{array}{l}\text { The organ transplantation agenda submitted to the Cabinet in } 2004 \text { was deferred in October 2006. This action } \\
\text { ignited an active campaign, where informed and investigative media reports and SIUT's bold and challenging } \\
\text { technical deliberations exposed the growing unethical lucrative kidney trade. }\end{array}$ \\
\hline 2007 & $\begin{array}{l}\text { Exploitative organ transplantation led to a judicial action in July 2007, whereby the Supreme Court of Pakistan } \\
\text { took a suo moto notice advising the Government to promulgate the transplantation law. }\end{array}$ \\
\hline 2007 & The transplantation ordinance was promulgated in September 2007 by the President of Pakistan. \\
\hline 2008 & $\begin{array}{l}\text { Attempts were made by the counter lobby through the Standing Committee for Health at the National Assembly } \\
\text { to water down the law by introducing loopholes implicitly condoning organ sale and allowing expatriates to } \\
\text { acquire kidneys for lucrative fees. These endeavours were rejected by the Standing Committees for Health and } \\
\text { Human Rights. }\end{array}$ \\
\hline 2008 & $\begin{array}{l}\text { A case was filed before the Federal Shariat Court of Pakistan, challenging the law, whereby } 12 \text { hearing sessions } \\
\text { were held in Islamabad, Lahore and Karachi, unanimously defeating all submitted objections and rendering all } \\
\text { stipulated clauses of the law sustained, including the illegality of all forms of organ sale. }\end{array}$ \\
\hline 2009 & $\begin{array}{l}\text { On } 23 \text { June 2009, the Supreme Court took suo moto notice against private hospitals accused of violating the law } \\
\text { and performing illegal transplantations, who when summoned by the court made commitments to comply with } \\
\text { the law. }\end{array}$ \\
\hline 2009 & $\begin{array}{l}\text { On } 12 \text { November 2009, the National Assembly of Pakistan unanimously passed the bill on the recommendation } \\
\text { of its Standing Committee on Health. }\end{array}$ \\
\hline 2010 & On 10 February 2010, the Senate of Pakistan passed the bill. \\
\hline 2010 & On 17 March 2010, the President of Pakistan signed the bill making it a law. \\
\hline
\end{tabular}

SIUT = Sindh Institute of Urology and Transplantation . 
age between siblings. The ordinance defined "close blood relatives" as parent, son, daughter, sister and brother, and included spouse provided that transplantation was voluntary, motivated and free of duress or coercion. However, in the case of non-availability of a close blood relative donor, the organ transplantation evaluation committee had the prerogative to allow donation by non-close blood relative donors after ensuring that such donation was voluntary. The ordinance was quite unambiguous that the donation of an organ or tissue from a living national should not be permissible to citizens of other countries.

\section{Donations of human organs or tissues after death}

The ordinance instructed that any person not less than 18 years of age may, before his or her death, in writing duly signed by the evaluation committee, donate any of his or her organs or tissues, and may also assign a medical institution or hospital recognized by the monitoring authority for transplantation. This donation willed after death could be revoked by the donor at any time during his or her lifetime.

\section{Evaluation committees}

Evaluation committees were constituted through the legislation and consisted of surgical, medical and transplantation specialists, nephrologists, a neurophysician and an intensivist where available, along with two local notables with a good record of social service. They were accountable for: (a) exercising control over transplantation procedures in medical institutions and hospitals for ensuring that no organ or tissue was retrieved from non-related living donor without the prior approval of the evaluating committee; (b) determining brain death of a person; (c) determining propriety of removal of a human organ from any living person using brain death protocol; and (d) determining fitness or otherwise for transplantation of a human organ into any other body.

\section{Monitoring authority}

A monitoring authority was established headed by the Federal Minister for Health and comprising of the Federal Health Secretary and seven eminent transplantation surgeons. The authority is responsible for:

- monitoring transplantations and enforcing prescribed standards for recognized medical institutions and hospitals;

- investigating allegations of breach of any provisions of the ordinance;

- inspecting medical institutions and hospitals to assess the quality of transplantation;

- establishing a national registry and national and regional networks evaluating the performance and quality outcome of transplantation centres;

- exploring and supporting international collaboration on xenotransplantation.

The monitoring authority is to appoint an administrator and other officers required to carry out its business.

\section{Penalties for commercial dealings in human organs}

Commercial dealings in human organs were rendered an offence, punishable with imprisonment for up to 10 years along with monetary penalty and possible removal of the practitioner's name from the register of the Pakistan Medical and Dental Council, initially for a 3-year period and permanently for subsequent offences. Activities constituting an offence included: (a) making or receiving any payment for supply of, or for an offer to supply, any human organ; (b) seeking to find a person willing to supply for payment any human organ; (c) offering to supply any human organ for payment; and (d) publishing or distributing any advertisement inviting persons to supply for payment any human organ, or offering to supply any human organ for payment, or indicating that the advertiser is willing to undertake any commercial arrangement.

Furthermore, transplantations were only to be carried out by transplantation surgeons and physicians after ensuring that written certification had been obtained from the evaluation committee. The monitoring authority was mandated to publish a list of medical institutions and hospitals that were recognized for the practice of operative surgery in transplantation of human organs and tissues. The Federal Government could revise this list when necessary.

\section{Implementation}

As stipulated in the legislation, soon after the approval of the ordinance, the national Human Organ and Tissues Transplantation Authority (HOTA) was established. HOTA is led by an administrator and has as members a number of senior medical experts nominated by the Ministry of Health. The WHO Representative is also a member, whose major role is to liaise WHO's technical support and expertise with HOTA. This institution has the primary focus of framing rules, certifying eligibility of hospitals for transplantation services and the professional expertise required. These functions are carried out through performance-monitoring inspections. The minimum basic criteria set by HOTA as preconditions for a hospital to be eligible to carry out transplantation procedures are outlined in Table 2 .

To permit donation by unrelated individuals, HOTA pursues a verification checklist where the authenticity of the recipient's claim of lacking eligible family members is endorsed only upon confirmation of lack of family members from the computerized National Database and Registration Authority and from the local authority of the recipient's residential area, along with blood grouping of any identified relatives when deemed necessary. 


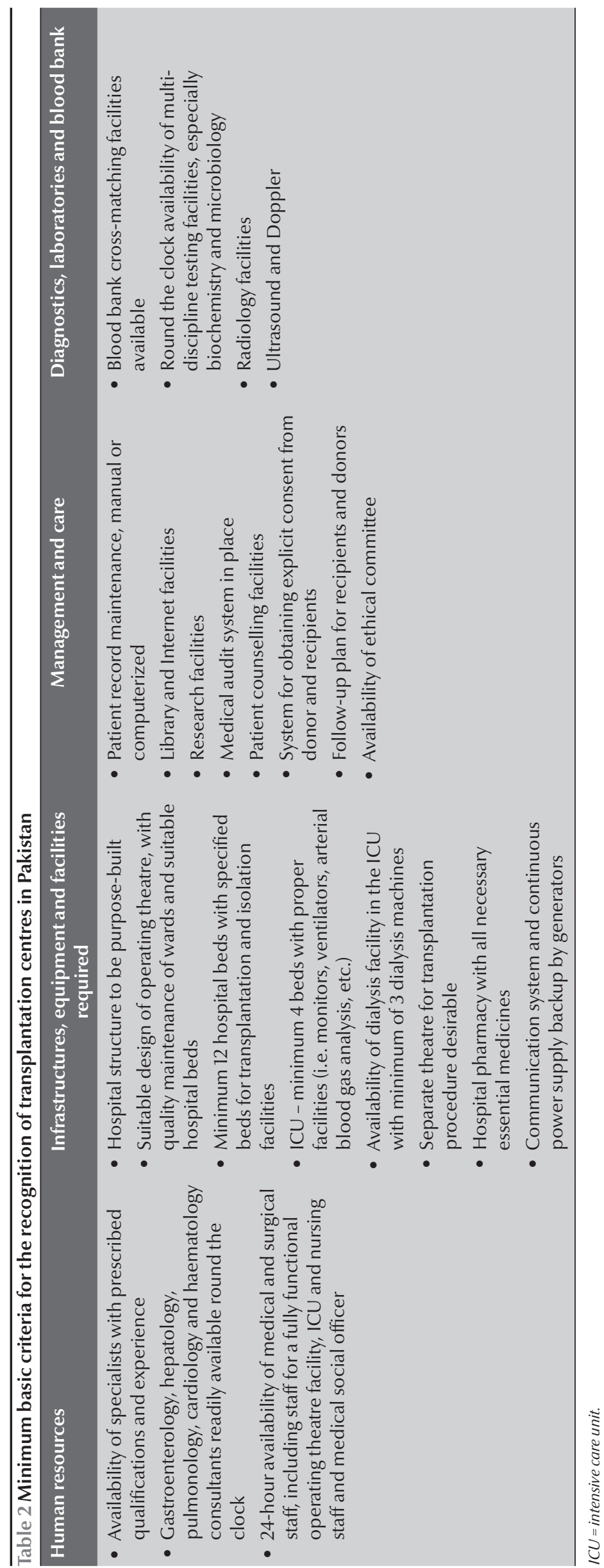

In the 2 years since the legislation was enacted, HOTA has accorded recognition to 42 hospitals and medical institutions to perform organ transplantation, following a satisfactory evaluation outcome.

Thenumbers of kidney transplants performed by 28 of the 42 HOTA-authorized hospitals, from the outset of the ordinance promulgation in 5 September 2007 to 31 December 2009 were recorded (Table 3). Most hospitals in Punjab performed transplantations from donors that were unrelated to their recipients; however, the donor-recipient analysis was consistent in all cases with HOTA legislation norms and guidelines.

\section{Implementation challenges Challenging the ordinance at the Federal Shariat Court}

Counter lobby groups aspiring to sustain the prelegislation status quo attempted to revoke the effective implementation of the law through a petition filed before the Federal Shariat Court. The petition aimed to remove the limitations imposed by the legislation on donors and prospective foreign recipients, claiming their inconsistency with Islamic principles. The petition also requested that the clauses related to Section 3 of the legislation, addressing donation by close blood relative; Section 5, relating to the evaluation committee; and Section 7, barring donations to foreign nationals, be declared un-Islamic and annulled. The Federal Shariat Court, through 12 hearings where experts, religious scholars, human rights activists and medical professionals participated as amicus curiae, unanimously rejected the petition and affirmed that the ethical practice of organ transplantation is a noble act fully condoned by Islam, while the sale of human organs is not permissible. The court also upheld that the Transplantation of Human Organs and Tissues Ordinance 2007 does not contradict the principles of Islam.

\section{Notice of the Supreme Court of Pakistan}

On 23 June 2009, the Supreme Court of Pakistan expressed concern that the sale of human organs for transplantation was continuing, despite the ordinance. A member of the bench noted that "It seems that provisions of the ordinance are not adhered to strictly and despite prohibition of the sale of human organs in Pakistan, the 


\begin{tabular}{|c|c|c|c|c|c|c|}
\hline \multirow[t]{2}{*}{ Hospitals with recorded transplantations } & \multicolumn{3}{|c|}{ Authorized hospitals } & \multicolumn{3}{|c|}{ Transplanted kidneys } \\
\hline & Public & Private & Total & Live related & $\begin{array}{l}\text { Live } \\
\text { unrelated }\end{array}$ & Total \\
\hline Islamabad/Punjab & 17 & 16 & 33 & 579 & 93 & 672 \\
\hline \multicolumn{7}{|l|}{ Islamabad } \\
\hline Pakistan Institute of Medical Sciences & & & & 7 & 0 & 7 \\
\hline Shifa International Hospital & & $\checkmark$ & & 39 & 0 & 39 \\
\hline Islamic International Medical Complex & & $\checkmark$ & & 33 & 0 & 33 \\
\hline \multicolumn{7}{|l|}{ Rawalpindi } \\
\hline Kidney Centre & & $\checkmark$ & & 45 & 32 & 77 \\
\hline Hearts International Hospital & & $\checkmark$ & & 2 & 3 & 5 \\
\hline Jinnah Memorial Hospital & & $\checkmark$ & & 73 & 0 & 73 \\
\hline Bilal Hospital & & $\checkmark$ & & 24 & 1 & 25 \\
\hline Armed Forces Institute of Urology & $\checkmark$ & & & 84 & 1 & 85 \\
\hline \multicolumn{7}{|l|}{ Lahore } \\
\hline National Hospital & & $\checkmark$ & & 14 & 23 & 37 \\
\hline Sharif City Hospital & & $\checkmark$ & & 23 & 10 & 33 \\
\hline Ihsan Mumtaz Hospital & & $\checkmark$ & & 78 & 9 & 87 \\
\hline Sarwat Anvar Hospital & & $\checkmark$ & & 6 & 9 & 15 \\
\hline Mayo Hospital & $\checkmark$ & & & 48 & 3 & 51 \\
\hline Adil Hospital & & $\checkmark$ & & 35 & 1 & 36 \\
\hline Shaikh Zayed Hospital & $\checkmark$ & $\checkmark$ & & 29 & 0 & 29 \\
\hline Surgimed Hospital & & $\checkmark$ & & 11 & 0 & 11 \\
\hline SIMS Services Hospital & & & & 5 & 0 & 5 \\
\hline Allama Iqbal Medical college & & & & 9 & 0 & 9 \\
\hline Akram Medical Complex & & $\checkmark$ & & 4 & 0 & 4 \\
\hline Masood Hospital & & $\checkmark$ & & 2 & 0 & 2 \\
\hline \multicolumn{7}{|l|}{ Multan/Bahawalpur } \\
\hline City Hospital Multan & & $\checkmark$ & & 2 & 1 & 3 \\
\hline Quaid-i-Azam Medical College & $\checkmark$ & & & 6 & 0 & 6 \\
\hline Sindh $^{\mathrm{a}}$ & 4 & 4 & 8 & 1033 & 1 & $1036^{a}$ \\
\hline \multicolumn{7}{|l|}{ Karachi } \\
\hline $\begin{array}{l}\text { Sindh Institute of Urology and } \\
\text { Transplantation (SIUT) }\end{array}$ & $\checkmark$ & & & 1020 & 0 & $1022^{\mathrm{a}}$ \\
\hline Karachi National Hospital & & & & 8 & 1 & 9 \\
\hline The Kidney Centre, Karachi & & & & 2 & 0 & 2 \\
\hline Jinnah Post Graduate Medical Centre & & & & 3 & 0 & 3 \\
\hline \multicolumn{7}{|l|}{ Khyber-Pakhtunkhwa } \\
\hline Centre for Kidney Diseases, Peshawar & 1 & & 1 & 12 & 0 & 12 \\
\hline \multicolumn{7}{|l|}{ Balochistan } \\
\hline Gilani Hospital, Quetta & 0 & 0 & 0 & $1^{\mathrm{b}}$ & 0 & 1 \\
\hline Total & 22 & 20 & 42 & 1625 & 94 & $1721^{\mathrm{a}}$ \\
\hline
\end{tabular}

${ }^{a}$ Two additional transplantations from deceased donors were performed at SIUT; ${ }^{b}$ Recognition withdrawn. Source: HOTA, Pakistan.

trade is going on allegedly in some hospitals", the names of which were mentioned in a letter sent by the Transplantation Society of Pakistan.
As a result of this strong legal notice, the owners of the private hospitals in question assured their full compliance with the ordinance.
Ratification of the bill by the National Assembly, the Senate and the President of Pakistan

On 13 November 2009, the National 
Assembly took up the Transplantation of Human Organs and Tissues Bill immediately on receipt of a supportive report from its Standing Committee on Health. The house unanimously adopted the bill, promptly signifying the importance that law-makers attach to regulating organ transplantation in Pakistan. Subsequently, on 10 February 2010, the Senate of Pakistan passed the bill and on 17 March 2010, the President of Pakistan signed the bill to make it a law.

\section{Discussion}

The evolution of organ transplantation and trade problems can only be truly appreciated in relation to the prevailing socioeconomic environment of any country $[1,7,12]$. In Pakistan, and elsewhere in developing countries, a tangible proportion of the population lives below the poverty line, predisposing many underprivileged individuals and families to coercive organ donation $[13,14]$. Major professional bodies, including Sindh Institute of Urology and Transplantation, the Transplantation Society of Pakistan, the Pakistan Society of Nephrology and the Pakistan Association of Urological Surgeons, supported by WHO, have been advocating for legislation denouncing the sale of kidneys for transplantation for over 2 decades. Since 2004, WHO has provided extensive technical advisory support to the Ministry of Health on ethical regulation of organ transplantation and suggested the banning of organ trafficking. The Ministry of Health and Sindh Institute of Urology and Transplantation pioneered the drafting of the law and took a catalytic role in speeding up the technical processes for regulating organ transplantation. This venture was supported by numerous professional and civil organizations as well as the media, whose deliberations and advocacy generated sufficient voice for action. These efforts forged an alliance between the Ministry of Health and the Standing Committee for Health of the National Assembly, culminating in the jointly mobilized technical and political support that led to the promulgation of this law.

With the promulgation of the ordinance, opportunities for unrelated donations became limited to the exceptional cases envisaged by the law, while buying and selling of organs became illegal and punishable offences, resulting in a complete ban of these practices, including organ donations to foreigners unless accompanied by related donors [15]. The need to develop an effective deceased donation programme to encompass the transplantation needs of the population was clearly recognized by the Government and professional medical organizations. Furthermore, measures to increase organ availability from deceased donors have been strongly recommended. This could be substantiated by health professional training, public advocacy and promotion, mobilization of religious scholars and bestowing recognition to families of deceased donors [16].

In accordance with constitutional provisions, the Federal Shariat Court is vested with the power and jurisdiction to test the laws on the criteria of Shariat with the assistance of religious scholars [17]. With jurisdiction to determine laws on Islamic principles, the court declared that the transplantation bill was not contrary to the injunctions of Islam.

Implementation of the law constitutes an uphill task, not achievable unless all stakeholders engaged in these activities extend support. Until such time when deceased donations become an operational reality, the Pakistan health system will face the challenge of contesting the predicted temptation of organ trafficking, which poses serious risk to the life of donors and recipients alike as such illegal practices would most likely be conducted in unacceptable settings that would endanger life.
The success of this new law therefore hinges on the collective efforts of the Government and society to combat all possible violations of the law [18].

To attain self-sufficiency in organ transplantation, health professionals and their associations in Pakistan must adhere to the stated norms of the act and perform transplantations from living donors with minimal physical and psychological risk [19]. This will avert jeopardizing public trust and will enhance the health system's ability to operate effectively within the parameters of the law, preserving the safety and ethics of this practice $[7,20]$. The decision to donate should be made in an environment that enables the potential donor to decide independently, without coercion or duress [4]. Of the 42 HOTA-authorized hospitals, 28 have performed 1721 kidney transplants following the legislation. Prospective research studies should be commissioned to evaluate the medium- and long-term impact of the legislation and to assess the extent to which the number of kidney transplants performed responds to the anticipated load in organ donation in Pakistan.

In the development of an organ transplantation structure in Pakistan, major areas require public education, including the ethical and Islamic perspectives related to live organ donation in general and to cadaver donation in particular [9]. Although this paper focuses on kidney transplantation, the legislation may be applied to other forms of organ transplants from live and cadaver donors alike. It may hopefully encourage the transplantation of other organs such as corneas and thus rectify the current situation whereby over $90 \%$ of corneas for transplants are imported. A better understanding is also needed regarding "brain death", legal heirs' right of substitute decisionmaking in the absence of anticipated will of the deceased, and the State's role in the case of unclaimed dead bodies $[9,14,21,22]$. The transgressors 
involved in kidney trafficking may continue appealing to the Supreme Court Appellate Bench to revert the Shariat Court verdict, hence the need to inculcate a high level of public education and build alliance with Islamic scholars and jurists.

To evaluate the public health contribution of organ transplantation services, the Ministry of Health needs to establish a database, for both donors and recipients, supported by the centres providing these services. The capacity of the health system to offer dialysis to end-stage chronic renal failure needs to be strengthened, to reduce patient morbidity and improve quality of life. Moreover, the Ministry of Health should closely monitor surgical, medical and immunosuppressive protocols and establish a mandatory 2-year follow-up of donors and recipients to provide medical, emotional and psychosocial support and also evaluate the outcome of these interventions nationwide.

\section{References}

1. Human organ transplantation in Europe: an overview. Luxembourg, European Commission, Directorate-General Health and Consumer Protection, Public Health and Risk Assessment Directorate, 2003.

2. Hakim NS, Papalois VE. History of organ and cell transplantation. London, Imperial College Press, 2003.

3. Song RL et al. Brain death and organ transplant legislation: analysis of 969 respondents by classroom questionnaire. Hepatobiliary Pancreatic Disease International, 2009, 8(5):483-493.

4. WHO guiding principles on human cell, tissue and organ transplantation (updated edition). Geneva, World Health Organization, 2008 (EB 123/5) (http://www.who.int/transplantation/ TxGP08-en.pdf).

5. Statement on human organ donation and transplantation. Edinburgh, World Medical Association, 2006.

6. Linden PK. History of solid organ transplantation and organ donation. Critical Care Clinics, 2009, 25(1):165-184.

7. Naqvi SAA et al. A socio-economic survey of kidney vendors in Pakistan. Transplant International, 2007, 20:934-939.

8. Jafar TH. Organ trafficking: global solution for a global problem. American Journal of Kidney Diseases, 2009, 54(6):1145-1157.

9. Al Qardawi Y. Organ transplantation in the Islamic sharia. Paper presented at the Conference of the Congregation of the Islamic Studies, Doha, Qatar, 2009.

10. Al-Khader AA. The Iranian transplant programme: comment from an Islamic perspective. Nephrology Dialysis Transplantation, 2002, 17(2):213-215.

11. Rizvi SA, Naqvi SAA. Renal replacement therapy in Pakistan. Saudi Journal of Kidney Diseases and Transplantation, 1996, 7(4):404-408.

12. Shimazono $Y$. The state of the international organ trade: a provisional picture based on integration of available information.
Bulletin of the World Health Organization, 2007, 85(12):901980.

13. Rizvi $\mathrm{AH}$ et al. Regulated compensated donation in Pakistan and Iran. Current Opinion in Organ Transplantation, 2009, 14 (2):124-128.

14. International summit on transplant tourism and organ trafficking: the declaration of Istanbul on organ trafficking and transplant tourism. ClinicalJournal of American Society of Nephrology, 2008, 3(5):1227-1231.

15. The transplantation of human organs and tissues: an ordinance. Ordinance Gazette of Pakistan, Government of Pakistan, 2007 (XLIII of 2007).

16. Abouna GM. Ethical issues in organ transplantation. Medical Principles and Practice, 2003, 12(1):54-69.

17. The constitution of Islamic Republic of Pakistan 1973 (Chapter 3A, Article 203). Islamabad, Islamic Republic of Pakistan, 1973.

18. Usmani AQ. From kidney bazaar to ethical practices in organ transplantation. Pakistan Journal of Medical Research, 2007, 46(3):56.

19. Rizvi SAH et al. Commercial transplants in local Pakistanis from vended kidneys: a socio-economic and outcome study. Transplant International, 2010, 22(6):615-621.

20. Noel L, Martin D. Progress towards national self-sufficiency in organ transplants [Editorial]. Bulletin of the World Health Organization, 2009, 87:647.

21. Robert DT, Miller FD. The dead donor rule and organ transplantation. New England Journal of Medicine, 2008, 359(7):674675.

22. Aldawood A et al. Organ donation after brain death: experience over five years in a tertiary hospital. Saudi Journal of Kidney Diseases and Transplantation, 2007, 18(1):60-64. 